\title{
Sahulia, a new endemic genus and a generic key to Sapotaceae in New Guinea
}

\author{
Ulf Swenson $^{1}$ [D \& Jennifer Kearey ${ }^{1}$
}

Summary. Sahulia suboppositifolia (Sapotaceae, Chrysophylloideae) is described and illustrated as a new monotypic genus from New Guinea. The species is so far only known from four collections made in lowland tropical rainforest near Lake Murray in the west and Koitaki east of Port Moresby. As a member of Sapotaceae with white latex, entire leaves, and flowers in fascicles, it is readily distinguished by the combination of opposite leaves, non-areolate venation, and almost $10 \mathrm{~mm}$ long green flowers with a bristle-like corolla margin consisting of short, rather thick, and pointing trichomes. We also provide a new generic key to Sapotaceae for New Guinea.

Key Words. new genus, Papua, Planchonella, taxonomy.

\section{Introduction}

Dutch botanists have long been very active in studying the flora of New Guinea, not the least Lam (1932), van Royen (1957), and Herrmann-Erlee \& van Royen (1957). Before molecular techniques were available, the classification of Sapotaceae was unstable with, for example, Planchonella Pierre being accepted, subsumed, resurrected, and again subsumed in Pouteria Aubl. (Dubard 1912; Baehni 1942; van Royen 1957; Pennington 1991). With the introduction of molecular and phylogenetic techniques, a new classification of Sapotaceae has been developed. Planchonella is evidently a good natural group while Pouteria is now restricted to species occurring in the New World and found in Asia and Oceania only as cultivated or escaped plants (Swenson \& Anderberg 2005; Swenson et al. 2008, 2013; Faria et al. 2017). Phylogenetics have revealed that species in New Guinea and New Caledonia earlier classified in Pouteria are better placed in Pichonia Pierre, Planchonella, Pleioluma (Baill.) Baehni, Pycnandra Benth., Sersalisia R.Br., and Van-royena Aubrév. One species with an aberrant combination of morphological characters, not corresponding to any of these natural groups, is Planchonella suboppositifolia H.J.Lam.

Planchonella suboppositifolia was described by Lam (1932) from New Guinea as "A remarkable plant, allied to P. chartacea (v.Muell.) H.J.L. from N. Australia, ...", without further comment. The species was later transferred to Pouteria by Baehni (1942), followed by van Royen (1957) who again placed it in Planchonella, citing only three (or four) available specimens. It differs from all other Planchonella in having opposite leaves (not alternate), tertiary veins perpendicular to the midvein (not reticulate or oblique), a sparsely pubescent corolla (not glabrous), and stamens that are inserted near the middle of the corolla tube (not close to the tube orifice). It further differs from other members of Sapotaceae in New Guinea such as Magodendron Vink, Pichonia, Pleioluma, and Sersalisia in the absence of the characteristic higher areolate leaf venation. One specimen (Pullen 7499), collected in 1967, housed in the Leiden herbarium, was studied by T. D. Pennington for his generic monograph (Pennington 1991), and determined to Pouteria without further comment. This specimen, however, was green enough and possible to use for molecular analysis.

Planchonella suboppositifolia was then included in a molecular phylogenetic study of Planchonella using nuclear ribosomal DNA (ETS, ITS), the nuclear gene $R P B 2$, and gap information (Swenson et al. in press). This analysis placed $P$. suboppositifolia as sister to a large clade including Amorphospermum F.Muell., Niemeyera F. Muell., Pycnandra, and Planchonella, yielding strong support for being a member of the clade with moderate support for the sister relationship. Considering the phylogenetic position and that the combination of morphological features is unique, it deserves to be recognised as a separate genus, here described as Sahulia Swenson (all cited specimens have been seen by the first author).

\section{Taxonomic Treatment}

Sahulia Swenson, gen. nov. Type: Planchonella suboppositifolia H.J.Lam

Hermaphroditic tree with white latex. Leaves simple, entire, opposite, clustered at branch tips; secondary venation brochidodromous with weak, submarginal

Accepted for publication 1 July 2020.

1 Swedish Museum of Natural History, Svante Arrhenius väg 3, SE-114 18, Stockholm, Sweden. e-mail: ulf.swenson@nrm.se 


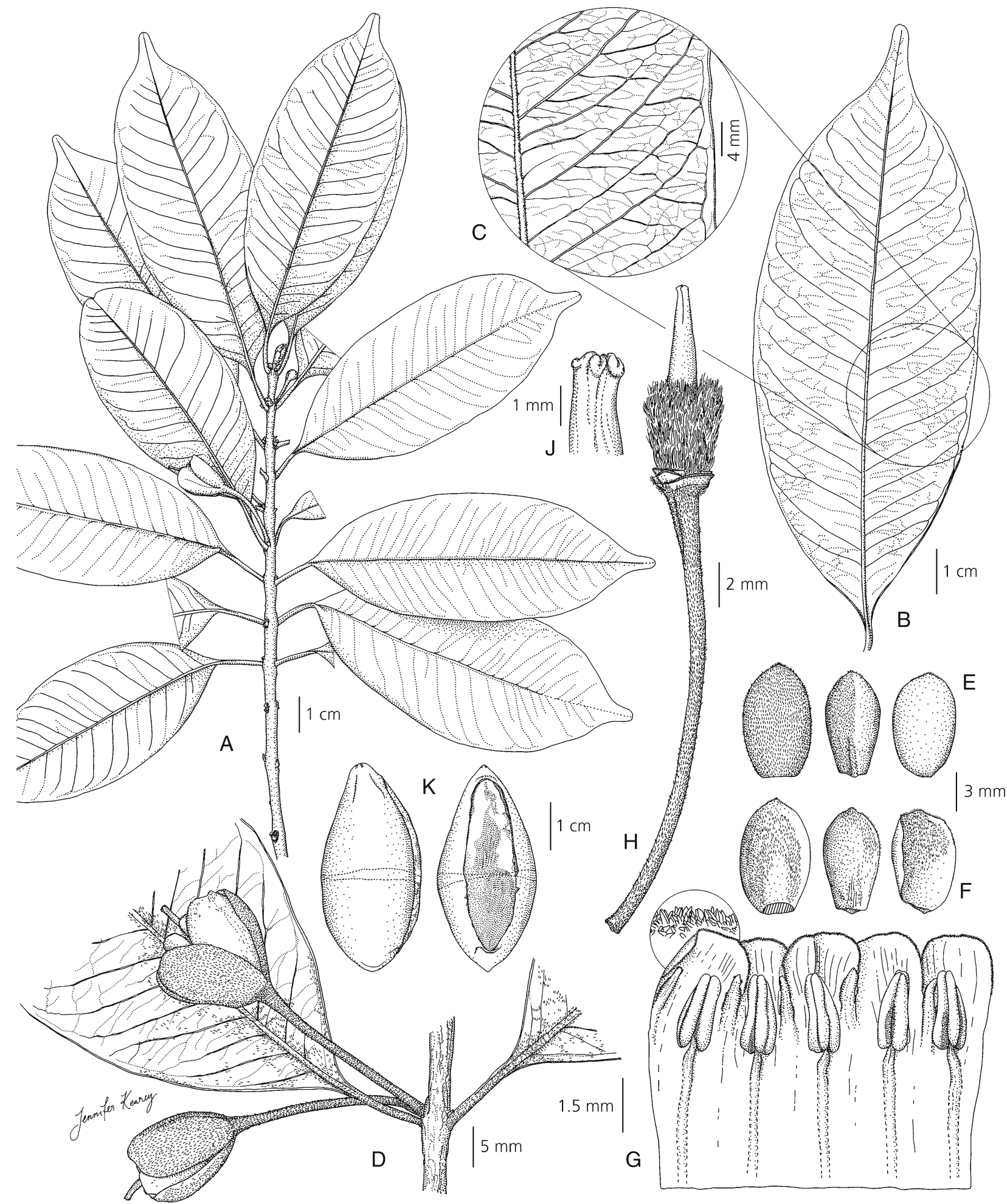

Fig. 1. Sahulia suboppositifolia. A habit; B leaf; C close-up of leaf venation; D fascicle of two flowers; E sepals, outer surface of outer (left), middle, and inner (right) sepal; $F$ as in $E$ but inner surface; $G$ inside view of corolla displaying minute bristle-like trichomes along the margins (with enlargement) of corolla lobes and staminodes; $\mathrm{H}$ pedicel and the pubescent gynoecium (sepals removed); J apex of style; $\mathrm{K}$ reconstructed seed showing side view (left) and seed scar view (right), the dotted lines indicate where this seed is cut. From Pullen 7499 ( $\mathrm{A}-\mathrm{J}$ ) and Lane-Poole 123 (K). DRAWN BY JeNNIFER KEAREY.

loops; tertiary venation horizontal near midvein, laxly reticulate in the distal part, higher venation not areolate. Flowers in fascicles, axillary, bisexual, 5merous. Sepals in a single whorl, free, quincuncial, 


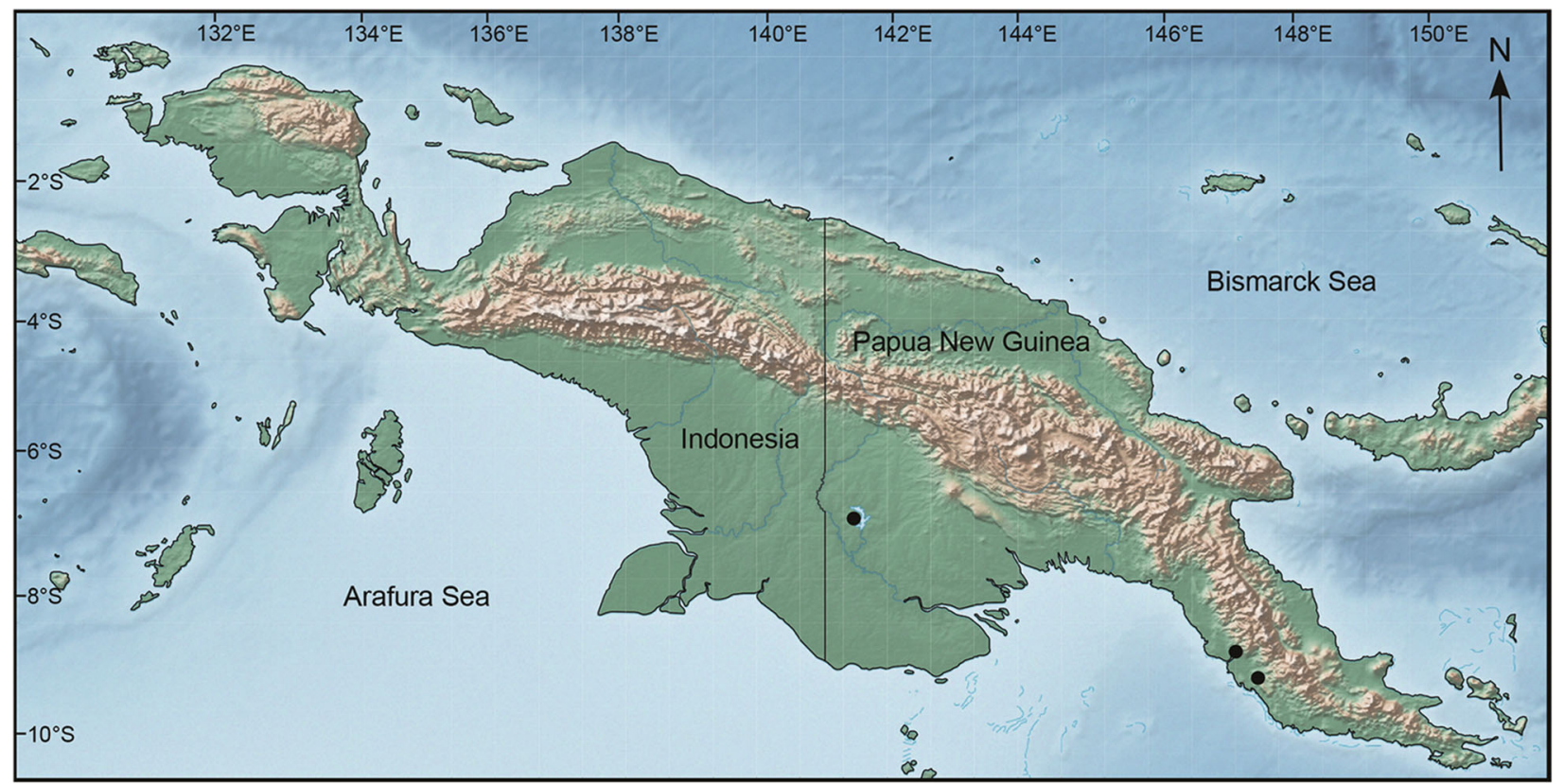

Map 1. Known distribution of Sahulia suboppositifolia in New Guinea

exposed outer surfaces tomentulose, overlapped parts glabrous. Corolla tubular, sparsely pubescent outside, glabrous inside, corolla tube slightly longer than the corolla lobes; corolla lobes entire, margins with minute, bristle-like trichomes. Stamens glabrous, inserted in middle of corolla tube; filaments adnate to the corolla tube. Staminodes flat, lanceolate, partly bristly along the margin with minute, bristle-like trichomes. Gynoecium hispid, ellipsoid; style exserted, glabrous, with small stigmatic areas at apex. Fruit poorly known, probably 1-seeded, ovoid, not laterally compressed, seed of the same form as the fruit; cotyledons foliaceous with a radicle extending below cotyledon commissure, endosperm present.

RECOGNITION. A Sapotaceae genus with (despite its species epithet) opposite leaves with which in New Guinea it only can be confused with Pichonia. However, Pichonia has areolate higher venation, which is absent in Sahulia. If flowers are available, the petal and staminode margins are bristle-like with short, rather thick, and pointing trichomes (possibly confused as papillae), a very rare feature in Chrysophylloideae and not known in any other species in New Guinea. The densely bristle-like margin is further distinguished from a ciliate margin, which is fringed of rather long and narrow trichomes, a feature not uncommon in the family.

Sahulia suboppositifolia (H.J.Lam) Swenson, comb. nov.

Basionym: Planchonella suboppositifolia H.J.Lam, Nova Guinea 14: 565 (1932). 三 Pouteria suboppositifolia (H.J. Lam) Baehni, Candollea 9: 413 (1942). Type: Papua
New Guinea, [Central Province], Aroa, [09 $03^{\circ} \mathrm{S}$, $\left.146^{\circ} 48^{\prime} \mathrm{E}\right]$, May 1922, C. E. Lane-Poole 123 (holotype BRI-AQ022584).

Tree to $30 \mathrm{~m}$ tall. Leaves opposite (rarely subopposite), thin, elliptic or slightly obovate, $8-13 \times 3.5-5.0 \mathrm{~cm}$ including the acumen, glabrous above, sparsely tomentulose with white trichomes below, glabrescent except for some persistent trichomes along the midvein; apex obtusely acuminate, acumen 5 $15 \mathrm{~mm}$ long; venation as described above, weak, secondaries of 9 - 16 pairs; base cuneate, sometimes slightly oblique; petiole (5 -) $10-15 \mathrm{~mm}$ long, tomentulose, glabrescent. Flowers $1-3$ in each fascicle; pedicel $15-25 \mathrm{~mm}$ long, tomentulose, fawn. Sepals $8-$ $12 \mathrm{~mm}$ long, broadly elliptic, with a differentiated fawn tomentum outside, the outer being entirely tomentulose, the partly overlapped sepal is tomentulose on the exposed surface but glabrous in its total length that is overlapped by the outer sepal, and the inner sepal is entirely glabrous; the inside of all sepals have trichomes on almost the entire surface except from the lower central part. Corolla green, $6-$ $9 \mathrm{~mm}$ long; anthers calcarate to $20 \%$, oblong, 1.8 $2.0 \mathrm{~mm}$ long. Gynoecium narrowly cone-shaped, c. $12 \mathrm{~mm}$ long. Fruit $62-75 \times 30-40 \mathrm{~mm}$, red when ripe; seeds ovoid, round, c. $45 \times 20 \mathrm{~mm}$; seed scar $30 \%$ of the circumference and $80 \%$ of seed length; testa brown, dull, woody, $2-3 \mathrm{~mm}$ thick (Fig. 1).

DISTRIBUTION. Endemic to New Guinea and currently only known from an area near Lake Murray (Western Province), and Aroa and Koitaki (east of Port Moresby) in the Central Province (Map 1). 
SPECIMENS EXAMINED. PAPUA NEW GUINEA: Central Province, Koitaki, 20 July 1935, Carr 12845 (BM, CANB, L); ibid., 26 July 1935, Carr 12892 (BM, CANB, K, S, SING); Western Province, western side of Lake Murray, 17 Oct. $1967,06^{\circ} 56^{\prime} \mathrm{S}, 141^{\circ} 25^{\prime} \mathrm{E}$, Pullen 7499 (BM, BRI, CANB, K, L, S, US).

HABITAT. Rainforest, probably from sea level to hills $450 \mathrm{~m}$ in altitude.

CONSERVATION STATUS. Data Deficient (IUCN 2012). Recent data on the population size and a more realistic distribution, or impact from deforestation, are unavailable.

PHENOLOGY. The phenology of this species is poorly known, but it had buds as well as flowers in
October, and the fruiting specimen was collected in May.

USES. Unknown but noted as "A hard straight grained dense timber" by C. E. Lane-Poole who collected the type specimen in May 1922.

ETYMOLOGY. The generic name Sahulia refers to the Sahul Shelf, comprising what today is Australia and New Guinea, a landmass colonised by Sapotaceae for approximately $52 \mathrm{Ma}$ (Bartish et al. 2011). The phylogenetic position of Sahulia as sister to Amorphospermum, Niemeyera, Pycnandra and Planchonella (Swenson et al. in press), indicates that the lineage is relatively old and belongs to one of the oldest splits in the subfamily that took place somewhere in the Sahul Shelf.

\section{Key to the Sapotaceae genera in New Guinea}

We here present the first dichotomous key to all genera of Sapotaceae in New Guinea following the most recent classification of Sapotaceae (Swenson \& Anderberg 2005; Swenson et al. 2013). There are 14 genera and about 75 described species distributed in subfamily Sarcospermatoideae (H.J.Lam) Swenson \& Anderb. (Sarcosperma Hook.f.), subfamily Sapotoideae Eaton (Burckella Pierre, Madhuca Buch.-Ham. ex J.F.Gmel., Manilkara Adans., Mimusops L., and
Palaquium Blanco), and another eight genera in subfamily Chrysophylloideae. Genera of Sapotaceae cannot be identified on phyllotaxy and vein patterns alone even if presence or absence of areolate venation is helpful. Flowers are ephemeral in Sapotaceae (Terra-Araujo et al. 2012), but calyces provide useful indications and persist after anthesis and are therefore a minimum for identification.

1. Leaves lacking stipels at the top of the petiole or base of blade; inflorescences 1 - many-flowered fascicles. . . . 2

1. Leaves with distinctive pair of stipels at the top of petiole or base of blade; inflorescences racemes or

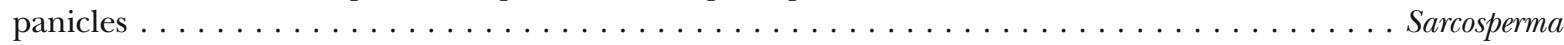

2. Calyx in 1 whorl, sepals partly overlapping, quincuncial or imbricate $\ldots \ldots \ldots \ldots$

2. Calyx in 2 whorls, sepals clearly arranged in an outer and an inner whorl $\ldots \ldots \ldots \ldots$

3. Calyx a single whorl of usually 5 quincuncial sepals; corolla lobes usually the same number as the sepals (except

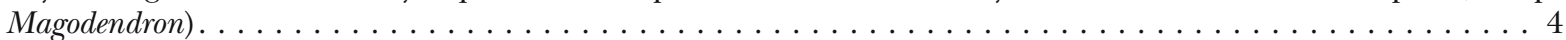

3. Calyx a single whorl of 4 sepals with margins of 2 sepals inside and 2 outside; corolla lobes 8 , imbricate . . Burckella

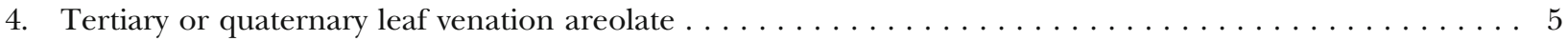

4. Tertiary or quaternary leaf venation never areolate $\ldots \ldots \ldots \ldots \ldots \ldots$

5. Flowers axillary or along branches; stamens (if present) 1 opposite each corolla lobe . . . . . . . . 6

5. Flowers born on trunk; stamens $2-4$ opposite each corolla lobe . . . . . . . . . . . . . . Magodendron

6. Stamens inserted in lower half of corolla tube; cotyledons foliaceous . . . . . . . . . . . . . . . Pleioluma

6. Stamens inserted in or just below corolla tube orifice; cotyledons plano-convex . . . . . . . . . . . . 7

7. Flowers cup-shaped; style simple, without visible stigmatic areas . . . . . . . . . . . . . Pichonia

7. Flowers tubular; style with visible stigmatic areas (high magnification) $\ldots \ldots \ldots \ldots$. . . . . . . . Sersalisia

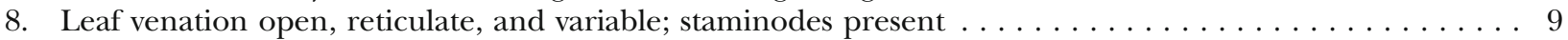

8. Leaf venation tight, \pm perpendicular to midvein; staminodes absent $\ldots \ldots \ldots \ldots \ldots$

9. Leaves alternate; stamens inserted just below corolla tube orifice; seeds often compressed, jolly-boat shaped

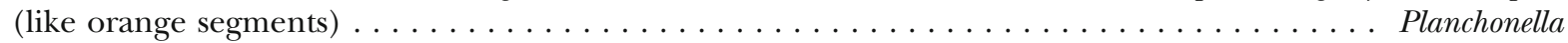

9. Leaves opposite; stamens inserted in middle of corolla tube; seeds ovoid . . . . . . . . . . . . . . Sahulia

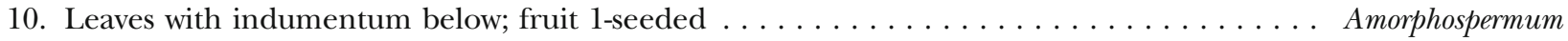

10. Leaves glabrous below (except along midvein); fruit usually 5 -seeded . . . . . . . . . . . . . Donella

11. Sepals 4 in 2 distinct whorls $(2 \times 2$ sepals $) \ldots \ldots \ldots \ldots \ldots \ldots \ldots \ldots$

11. Sepals 6 or 8 in 2 distinct whorls $(2 \times 3$ or $2 \times 4$ sepals $) \ldots \ldots \ldots \ldots \ldots$

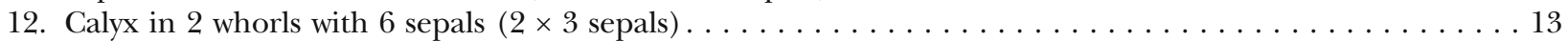

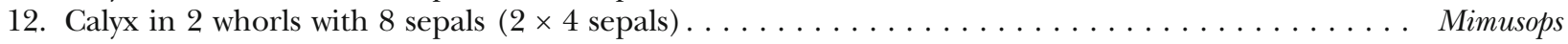

13. Staminodes present; stamens 6 ; corolla lobes divided into 3 segments . . . . . . . . . . . . Manilkara

13. Staminodes absent; stamens $(10-) 12(-30)$; corolla lobes entire . . . . . . . . . . . . . . . Palaquium 


\section{Acknowledgements}

We are grateful to two reviewers that promptly handled and provided useful comments on this manuscript. A special thank you is directed to Gerard Thijsse in Leiden who provided permission to remove a leaf fragment from one specimen, which eventually resulted in this new genus. Brendan Lepschi (CANB) is warmly thanked for his hospitality and sharing duplicates with $\mathrm{S}$ of this so rarely collected genus. This research received support from the SYNTHESYS Project www.synthesys.info which is financed by European Community Research Infrastructure Action under the FP7 "Capacities" Program. Travelling support to USA for visiting various herbaria was provided by the Royal Swedish Academy of Sciences.

Funding Open access funding provided by Swedish Museum of Natural History.

Open Access This article is licensed under a Creative Commons Attribution 4.0 International License, which permits use, sharing, adaptation, distribution and reproduction in any medium or format, as long as you give appropriate credit to the original author(s) and the source, provide a link to the Creative Commons licence, and indicate if changes were made. The images or other third party material in this article are included in the article's Creative Commons licence, unless indicated otherwise in a credit line to the material. If material is not included in the article's Creative Commons licence and your intended use is not permitted by statutory regulation or exceeds the permitted use, you will need to obtain permission directly from the copyright holder. To view a copy of this licence, visit http://creativecommons.org/ licenses/by/4.0/.

\section{References}

Baehni, C. (1942). Mémoires sur les Sapotacées, 2: le genre Pouteria. Candollea 9: 147 - 476.

Bartish, I. V., Antonelli, A., Richardson, J. E. \& Swenson, U. (2011). Vicariance or long-distance dispersal: historical biogeography of the pantropical subfamily Chrysophylloideae (Sapotaceae). J. Biogeogr. 38: 177 - 190.

Dubard, M. (1912). Les Sapotacées du groupe des Sideroxylinées. Ann. Mus. Colon. Marseille, sér. 2, 10:1- 90.
Faria, A. D., Pirani, J. R., da Silva Ribeiro, J. E. L., Nylinder, S., Terra-Araujo, M. H., Vieira, P. P. \& Swenson, U. (2017). Towards a natural classification of Sapotaceae subfamily Chrysophylloideae in the Neotropics. Bot. J. Linn. Soc. 185: 27 - 55.

Herrmann-Erlee, M. P. M. \& van Royen, P. (1957). Revision of the Sapotaceae of the Malaysian area in a wider sense. IX. Pouteria Aublet. Blumea 8: 452 509.

International Union for Conservation of Nature (2012). IUCN Red List Categories and Criteria: Version 3.1, Second edition. IUCN, Gland \& Cambridge.

Lam, H. J. (1932). Enumeration of the Sapotaceae, thus far known from New Guinea. Nova Guinea 14: 549 - 570, pl. $94-129$.

Pennington, T. D. (1991). The Genera of Sapotaceae. Royal Botanic Gardens, Kew.

Swenson, U. \& Anderberg, A. A. (2005). Phylogeny, character evolution, and classification of Sapotaceae (Ericales). Cladistics 21: $101-130$.

, Richardson, J. E. \& Bartish, I. V. (2008). Multigene phylogeny of the pantropical subfamily Chrysophylloideae (Sapotaceae): evidence of generic polyphyly and extensive morphological homoplasy. Cladistics 24: 1006 - 1031.

, Nylinder, S. \& Munzinger, J. (2013). Towards a natural classification of Sapotaceae subfamily Chrysophylloideae in Oceania and Southeast Asia based on nuclear sequence data. Taxon 63: $746-$ 770 .

, Lowry II, P. P., Cronholm, B. \& Nylinder, S. (in press). Resolving the relationships of the enigmatic Sapotaceae genera Beauvisagea and Boerlagella, and the position of Planchonella suboppositifolia. Taxon.

Terra-Araujo, M. H., Faria, A. D., da Silva Ribeiro, J. E. L. \& Swenson, U. (2012). Flower biology and subspecies concepts in Micropholis guyanensis (Sapotaceae): evidence of ephemeral flowers in the family. Austral. Syst. Bot. 25: $295-303$.

van Royen, P. (1957). Revision of the Sapotaceae of the Malaysian area in a wider sense. VII. Planchonella Pierre. Blumea 8: 235 - 445.

\section{Publisher's Note}

Springer Nature remains neutral with regard to jurisdictional claims in published maps and institutional affiliations. 